\title{
Spent sulfuric acid plant catalyst: valuable resource of vanadium or risky residue? Process comparison for environmental implications
}

\author{
Bartosz Mikoda $^{1}$ (D) $\cdot$ Anna Potysz $^{2}$ (D) $\cdot$ Agnieszka Gruszecka-Kosowska $^{1}$ (D) $\cdot$ Ewa Kmiecik $^{1}$ (D) $\cdot$ Anna Tomczyk $^{1}$ (D)
}

Received: 4 March 2020 / Accepted: 20 October 2020 / Published online: 27 October 2020

(C) The Author(s) 2020

\begin{abstract}
The enormous amount of spent catalysts generated worldwide may pose a risk to the environment because of their high load of metals, including vanadium. The latter may be mobilized and released to the environment if managed improperly. Moreover, the catalysts could be considered as secondary resources rather than waste. This study aimed at the efficient extraction of vanadium from spent desulfurization catalyst (SDC) from a sulfuric acid production plant. The raw SDC and the post-extraction residues were characterized in terms of their chemical and phase composition. The metal mobility from the materials was examined with both single-step and multi-step extractions. The environmental risk assessment was performed using sequential extraction. The study revealed that both tested methods (citric acid leaching and bioleaching with Acidithiobacillus thiooxidans) enable the extraction of nearly $96 \%$ of V from SDC with a simultaneous reduction of metal mobility. However, the bacterial treatment was found more suitable. The leached residue was mostly (>90\%) composed of $\mathrm{SiO}_{2}$, which makes it a potential candidate for application in construction (e.g., concrete mixtures) after additional examinations. The study highlights the need to develop a metal extraction process for SDC in a way that metal-free residue could be a final product.
\end{abstract}

Keywords Vanadium - Metal recovery $\cdot$ Waste management $\cdot$ Environmental risk $\cdot$ Secondary resources $\cdot$ Sustainable development $\cdot$ Biohydrometallurgy

\section{Introduction}

Having a high-quality living environment is of great importance for humans. However, industrial development deteriorates the environment, which can lead to harmful effects on living organisms, including humans (Mikoda et al. 2017). One method that ensures both high-quality products and a cleaner environment is catalysis (from Greek katalein-decompose). In this process, catalysts (substances that modify chemical reactions without undergoing any reactions themselves-

Responsible Editor: Philippe Garrigues

Bartosz Mikoda bartosz.mikoda@agh.edu.pl

1 Faculty of Geology, Geophysics and Environmental Protection, AGH University of Science and Technology, al. A. Mickiewicza 30, 30-059 Krakow, Poland

2 Institute of Geological Sciences, University of Wrocław, Cybulskiego 30, 50-205 Wrocław, Poland mostly solid-state) are used to remove undesired constituents from the mixture of interest (Alvarez-Amparán and CedeñoCaero 2017). Various reactions are prompted with the use of catalysts, such as cleaning engine fumes, processing heavy crude oil, and oxidation or reduction of given elements (e.g., sulfur, nitrogen) in flue gas emissions. Different applications require different chemical compositions and unique properties. However, some common features such as high specific surface area and the presence of an active compound (usually metals, for example $\mathrm{Co}, \mathrm{Mo}, \mathrm{Ni}, \mathrm{V}, \mathrm{W}, \mathrm{Pt}, \mathrm{Pd}$ ) doped on a support phase (e.g., $\mathrm{SiO}_{2}, \mathrm{Al}_{2} \mathrm{O}_{3}, \mathrm{TiO}_{2}$ ) (Marafi et al. 2017; Cecilia et al. 2018). Catalysts have different life cycles (1-2 years for desulfurization, 3-5 years for nitrogen reduction), which can be shortened by factors such as the formation of coke, precipitation of metal salts, or adsorption of organic compounds. These factors either reduce the number of active sites or plug the pore system (Vogelaar et al. 2010; Maity et al. 2012). Eventually, the catalysts become unusable and must be replaced. The spent catalysts are often loaded with metals, oil, or coke, which makes them hazardous and hampers their use. Many are disposed of on sites dedicated to hazardous waste 
(Marafi and Stanislaus 2008). The spent catalysts generated worldwide include 700,000 to 900,000 tons of spent fluid catalytic cracking (FCC) residues (Muddanna and Baral 2019); up to 200,000 tons of catalyst from petroleum industry (Pathak et al. 2018); up to 40,000 tons of catalyst from sulfuric acid production (Nikiforova et al. 2017); and up to 38,000 tons of selective catalytic reduction (SCR) waste in China itself (Dai et al. 2018). These numbers force researchers to find comprehensive methods of economic and environmentfriendly use of catalysts.

Waste materials from catalytic activities are important as prospective secondary source of metals (Pathak et al. 2014; Akcil et al. 2015). These residues may be used after metal recovery if environmental standards are met. For many years, research efforts have been undertaken to find efficient solutions for catalyst utilization. Two methods that have been considered for this were deoiling or decoking and metal extraction or recovery (Al-Sheeha et al. 2013; Wiecka et al. 2020). Using unprocessed spent catalysts in the production of new catalysts or using them as additives to other useful materials also has been explored through the years (Furimsky and Biagini 1996; Trochez et al. 2015; Marafi et al. 2017). However, it is not always possible to remove oil, coke, or metals from the catalyst. In that case, the material becomes waste and it must be discarded.

Most methods for removing metals from spent catalysts are physical (pyrometallurgy), chemical (hydrometallurgy), or biological (bioleaching). Pyrometallurgical methods are mainly used to process automotive catalysts to recover noble metals such as Pt or Pd (Peng et al. 2017). However, pyrometallurgy has huge disadvantages, namely the need for special equipment and high energy consumption. Moreover, concentrated metals must be refined (Ding et al. 2019; Pathak et al. 2020; Wiecka et al. 2020). Therefore, the application of hightemperature treatment is limited from both environmental and economic viewpoints. Recently, (bio)leaching with chemical and bacterial means using a plethora of lixiviants and bacterial strains has attracted a great deal of attention from researchers worldwide (Asghari et al. 2013; Pradhan et al. 2013; Srichandan et al. 2014; Vyas and Ting 2016; Vyas and Ting 2018; Pathak et al. 2020; Le and Lee 2020). Both chemical and biological leaching procedures led to high yields of released metals (even up to 100\%) in both single-step and multi-step processes, and in combined chemical-biological processes. The metals in pregnant leach solutions may be either chemically precipitated or recovered using ion-exchange resins (Mazurek 2013; Innocenzi et al. 2014; Sethurajan et al. 2016; Pradhan et al. 2020).

The "raw" spent catalysts pose a threat to the environment because metals concentrated in these wastes are in high amounts and in mobile forms (Dai et al. 2018). Treating these wastes can significantly reduce the mobility of metals, which
Pathak et al. $(2014,2018)$ proved using chemical leaching and bioleaching. Biological treatment reduced the mobility of metals, so that most of them (98-99\%) were in residual fraction after four-step sequential extraction. (Bio)hydrometallurgical treatment not only causes the recovery of metals present in catalysts but also enhances the environmental stability of these wastes, which is more encouraging in terms of their further application.

The novelty of this study is mainly related to "green" approach applied that was a treatment generating residue depleted in vanadium. The element was recovered as a value. It has to be emphasized that recently the European Union places a great focus to supply raw materials. The EU economy and the list of critical raw materials have been recently upgraded (European Commission 2020). Among the raw materials identified by the European Commission, vanadium is included. Therefore, the current action policy adopted by the EU is oriented to foster raw material recycling and to promote research on recovery of raw materials. In these regards, sustainable waste management requires an extension of life cycle of product, meaning that it encourages to collect the spent desulfurization catalyst and further treat it as secondary resource rather than considering it as end-of-life product.

This study was aimed to define an efficient method to extract vanadium from spent desulfurization catalyst (SDC) from the sulfuric acid plant and to characterize post-(bio)leaching residues in terms of environmental risk. Leaching of $\mathrm{V}$ was carried out using organic lixiviant (citric acid (CA)) and bacterial strain Acidithiobacillus thiooxidans (AT). The standardized protocols (both single-step and multi-step) were applied to assess the environmental stability of both raw SDC and leached residues.

\section{Materials and methods}

\section{Characterization of raw and (bio)leached catalyst}

The SDC sample was received from a sulfuric acid production plant, which is a unit of a copper smelter. The catalyst is used there to oxidize $\mathrm{SO}_{2}$ to $\mathrm{SO}_{3}$, which is later utilized for $\mathrm{H}_{2} \mathrm{SO}_{4}$ production. The as-received sample consisted of $10-\mathrm{mm}$ yellow granules (Fig. 1a). A polished section was created on one granule (Fig. 1c), which was later subjected to microscopic observations using an optical microscope with reflected light (Nikon Eclipse LV100POL). Subsequently, selected areas were examined using a scanning electron microscope (FEI Quanta 200 FEG) coupled with an EDAX energy-dispersion spectrometer (SEM-EDS). The operating parameters were as follows: low vacuum mode, $20 \mathrm{kV}$ accelerating voltage, $10 \mathrm{nA}$ beam current, $50 \mathrm{~s}$ counting time, $34^{\circ}$ take-off angle. 


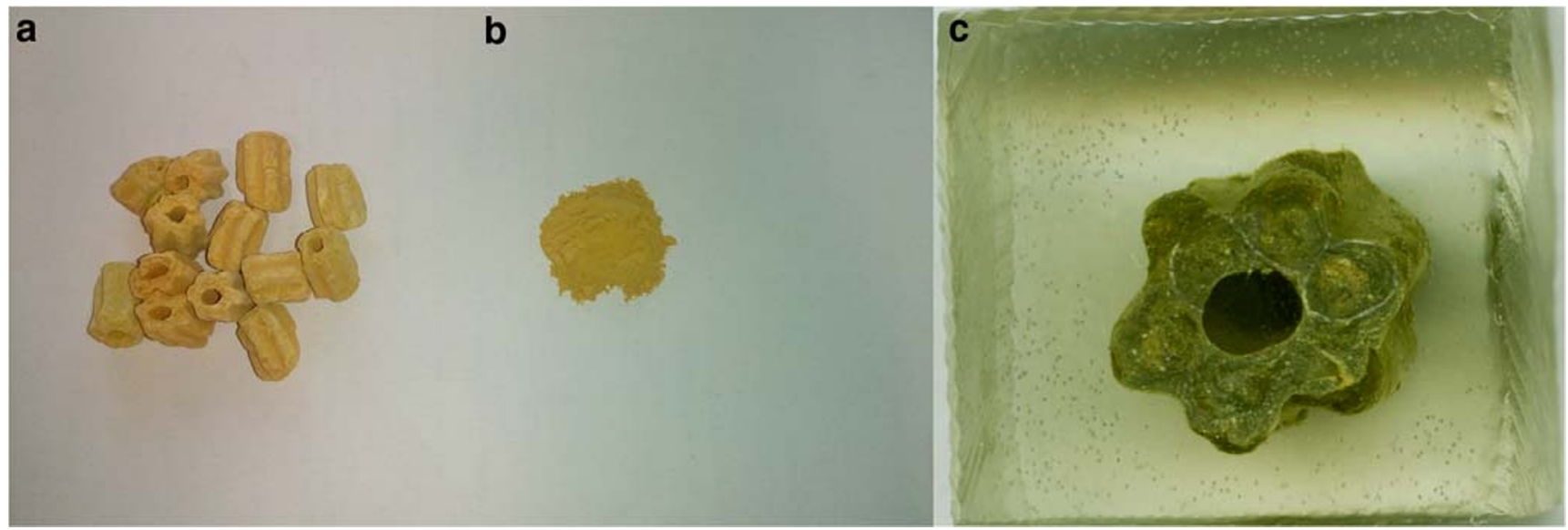

Fig. 1 Photographs of SDC samples: as-received (a), comminuted and sieved (b), and polished section (c)

The phase and chemical characteristics of raw and leached residues were determined using X-ray diffraction (XRD) and $\mathrm{X}$-ray fluorescence (XRF), respectively. XRD pattern was created with the Rigaku MiniFlex 600 device, on $0.5 \mathrm{~g}$ sample comminuted to $<5 \mu \mathrm{m}$, with the following working parameters: $\mathrm{Cu}-\mathrm{K} \alpha$ radiation, $3-75^{\circ} 2 \theta$ range, $0.05^{\circ}$ step width. The XRD results were processed with XRAYAN software coupled with PDF-4 database. The chemical oxide composition was determined using the Rigaku ZSX Primus II apparatus (X-ray tube: end-window, with $\mathrm{Rh}$ anode; $4 \mathrm{~kW}$ power) from $4.5 \mathrm{~g}$ sample powdered to $<100 \mu \mathrm{m}$ mixed with $1.5 \mathrm{~g}$ of CELLEOX® binding aid to form a pellet. The wave intensities were calculated to oxide composition using the fundamental parameter method.

Specific surface area (SSA) of raw and leached residues was determined using the $\mathrm{N}_{2}$ adsorption/desorption method in $77 \mathrm{~K}$ temperature with Micromeritics ASAP 2020 apparatus. $0.5 \mathrm{~g}$ portions of each residue were heated at $105^{\circ} \mathrm{C}$ for $12 \mathrm{~h}$ before taking the measurements. The Brunauer-EmmettTeller (BET) isotherm was used to characterize the specific surface area of the examined materials.

\section{Vanadium extraction}

The SDC sample has been comminuted (Fig. 1b) and sieved using two sets of sieves $(0.1 \mathrm{~mm}$ and $0.2 \mathrm{~mm})$ to investigate the effect of particle size on leaching efficiency. The citric acid (CA) solutions $(0.1 \mathrm{M}$ and $1 \mathrm{M})$ were used to evaluate the impact of acid concentration on V leaching. The third parameter used to optimize the process was pulp density (PD), which was evaluated in the range between 1 and $20 \%$. The extraction rate was analyzed in the time frame of $8-72 \mathrm{~h}$. The orbital shaker was set at $150 \mathrm{rpm}$ speed.

The bacterial extraction was performed using the gramnegative bacterial strain Acidithiobacillus thiooxidans (AT; DSM 9463) provided by Leibniz-Institut DSMZ (Deutsche Sammlung von Mikroorganismen und Zellkulturen $\mathrm{GmbH}$ ).
The AT strain was cultivated in a medium consisting of (all reagents of analytical grade, Merck, Germany) $2 \mathrm{~g}$ $\left(\mathrm{NH}_{4}\right)_{2} \mathrm{SO}_{4}, 0.25 \mathrm{~g} \mathrm{MgSO}_{4} \cdot 7 \mathrm{H}_{2} \mathrm{O}, 0.1 \mathrm{~g} \mathrm{~K}_{2} \mathrm{HPO}_{4}, 0.1 \mathrm{~g}$ $\mathrm{KCl}$, and $1 \%(\mathrm{w} / \mathrm{v})$ elemental sulfur per $1 \mathrm{dm}^{3}$ of ultrapure water (Millipore, Milli-Q), with $\mathrm{pH}$ adjusted to 2.5 using $10 \mathrm{M}$ $\mathrm{H}_{2} \mathrm{SO}_{4}$ (Potysz et al. 2020). The biotic experiments were conducted in Erlenmeyer flasks, where portions of SDC were mixed with $50 \mathrm{~cm}^{3}$ of fresh medium, $2 \%$ (w/v) of elemental $\mathrm{S}$, and $2 \%(\mathrm{v} / \mathrm{v})$ of bacterial inoculum. The abiotic tests were also conducted identically, except from the inoculum addition. Experiments were extended from 1 to 28 days using pulp densities (PD) of 1 to $20 \%$.

An earlier study (Mikoda et al. 2020) revealed that the optimal extraction conditions were 100-200 $\mu \mathrm{m}$ particle size (for both extractions), $48 \mathrm{~h}$ time and 10\% PD (CA), and 21 days' time and 2\% PD (AT), giving V extraction yields of $95 \%$ (CA) and 93\% (AT). Therefore, these conditions were applied again to get the materials for this study.

\section{Environmental risk assessment study}

\section{Leaching of elements with simulated rainfall}

The raw and leached SDC samples were subjected to leaching tests using standardized environmental protocols accepted worldwide. The discharge of metals from SDC samples when exposed to artificial rainfall was assessed using the EPA 1312 SPLP test. In this experiment, $1 \mathrm{~g}$ of each residue was put into separate $50 \mathrm{~cm}^{3}$ Falcon tubes filled with $20 \mathrm{~cm}^{3}$ of ultrapure water, acidified to $\mathrm{pH} 4.20 \pm 0.05$ using a mixture of $95 \%$ $\mathrm{H}_{2} \mathrm{SO}_{4}$ and $65 \% \mathrm{HNO}_{3}$ (60:40 volume ratio). The samples were shaken for $18 \mathrm{~h}$ (150 rpm speed), centrifuged, filtered with Whatman $0.45 \mu \mathrm{m}$ syringe filters, acidified with $0.1 \mathrm{~cm}^{3}$ of $65 \% \mathrm{HNO}_{3}$, and stored at $4{ }^{\circ} \mathrm{C}$ for analysis. 


\section{Forms of metal occurrence in raw and (bio)leached catalyst}

The fractionation of metals in raw and leached SDC materials was evaluated using a four-step sequential extraction protocol, stemming from a three-step procedure proposed by BCR (Pueyo et al. 2008). BCR extraction causes the release of four fractions (Table 1): exchangeable F1 (leached with $0.11 \mathrm{M}$ acetic acid) which represents adsorbed metals easily affected by the ionic composition of water; reducible F2 (leached with $0.11 \mathrm{M}$ hydroxylamine hydrochloride with $\mathrm{pH}$ adjusted to 2) which corresponds to metals affected by anoxic conditions; oxidizable F3 (leached with $30 \%$ hydrogen peroxide and $1 \mathrm{M}$ ammonium acetate with $\mathrm{pH}$ adjusted to 2), corresponding to metals released during highly oxic conditions, bound to organic matter and/or sulfides; and residual F4 (digested with aqua regia), representing metals bound to the crystal lattice of the material. The analysis of metal binding forms was conducted on $1 \mathrm{~g}$ sample of each material, mixed with the lixiviant for a given time (Table 1) in $50 \mathrm{~cm}^{3}$ Falcon polypropylene tubes. The shaking speed was $150 \mathrm{rpm}$. The tubes were centrifuged after the extraction, and the liquid samples were filtered with Whatman $0.45 \mu \mathrm{m}$ syringe filters, acidified with $0.1 \mathrm{~cm}^{3}$ of $65 \% \mathrm{HNO}_{3}$, and stored in $4{ }^{\circ} \mathrm{C}$ for analysis. The solid samples were washed with ultrapure water and subjected to the subsequent extraction step. The first part of the 3rd step $\left(\mathrm{H}_{2} \mathrm{O}_{2}\right.$ leaching) was conducted on a water bath. The 4 th step (aqua regia digestion) was performed using SCP Science DigiPrep HT 250 apparatus (Quebec, Canada) with $250 \mathrm{~cm}^{3}$ glass tubes. The liquid samples from the 4th step were diluted to $50 \mathrm{~cm}^{3}$ with ultrapure water, filtered using paper filters, and then subjected to the same procedure as the other liquid samples.

\section{Environmental risk indices}

The results of the sequential extraction procedure were used to evaluate the potential environmental risk of raw and leached SDC residues. In this study, a reduced partition index $\left(I_{\mathrm{R}}\right)$ and a risk assessment code (RAC) were used to assay the potential environmental risk posed by the spent catalyst before and after (bio)leaching.
The $I_{\mathrm{R}}$ is a commonly used index since it gives an insight into the relative binding intensity of an element in a solid matrix (Miretzky et al. 2011). $I_{\mathrm{R}}$ is defined by (Eq. 1):

$I_{\mathrm{R}}=\sum_{i=1}^{k} i^{2} F i / k^{2}$

where $i$ is the index number of the BCR sequential extraction step, $k=4$ (total steps in BCR sequential extraction), and $F i$ is the percentage of a particular metal in fraction $i$. The values of $I_{\mathrm{R}}$ are between 0.06 and 1.00 . The lower the $I_{\mathrm{R}}$ value, the weaker the binding of a metal, which corresponds to higher mobility.

The RAC index is indirectly related to $I_{\mathrm{R}}$ (the higher the RAC, the lower the $I_{\mathrm{R}}$ ) and reflects the mobility of metals (Gusiatin and Kulikowska 2014). It is defined by (Eq. 2):

$\mathrm{RAC}=\frac{C_{\mathrm{m}}}{C_{\text {total }}} \times 100 \%$

where $C_{\mathrm{m}}$ is a metal concentration in exchangeable fraction and $C_{\text {total }}$ is the total concentration of the given metal. Based on the F1 fraction, the RAC can have values from 1 to $100 \%$ : $<1 \%$ (no risk), 1 to $10 \%$ (low risk), 11 to $30 \%$ (medium risk), 31 to $50 \%$ (high risk), and $>50 \%$ (very high risk) for a given metal.

\section{Analysis of vanadium content in liquid samples}

The solutions, filtered and acidified (according to the procedure described in each section), were analyzed using inductively coupled plasma mass spectrometry (ICP-MS; Perkin Elmer ELAN 6100 device) according to the ISO 17294-2:2016 protocol. The apparatus was calibrated using multielement ICP standards provided by Merck (Germany). The QA/QC was performed by analyzing blank and duplicate samples and duplicate analysis of randomly chosen samples. The limits of quantification for the specific elements were as follows (in $\mathrm{mg} \mathrm{dm}^{-3}$ ): Al: 0.005, Fe: 0.02, K: 0.05, Mg: 0.001, Na: 0.01, S: 0.1, and V: 0.001. The results were multiplied by a liquid-to-solid ratio to express the leaching yields in $\mathrm{mg}$ per $\mathrm{kg}$ of catalyst.
Table 1 Parameters of sequential extraction with targeted fractions according to modified BCR procedure (Pueyo et al. 2008)

\begin{tabular}{lllllll}
\hline Step & Chemical agent & $\mathrm{pH}$ & SSR & Conditions & Time (h) & Fraction \\
\hline I & $40 \mathrm{~cm}^{3} 1 \mathrm{M} \mathrm{C}_{2} \mathrm{H}_{4} \mathrm{O}_{2}$ & 3 & $1: 40$ & Shaking (RT) & 16 & Exchangeable (F1) \\
II & $40 \mathrm{~cm}^{3} 0.1 \mathrm{M}\left[\mathrm{NH}_{3} \mathrm{OH}\right] \mathrm{Cl}$ & 2 & $1: 40$ & Shaking (RT) & 16 & Reducible (F2) \\
IIIa & $2 \times 10 \mathrm{~cm}^{3} 30 \% \mathrm{H}_{2} \mathrm{O}_{2}$ & $\mathrm{~ns}$ & $1: 10$ & Heating $\left(85^{\circ} \mathrm{C}\right)$ & $2 \times 1$ & Oxidizable (F3) \\
IIIb & $50 \mathrm{~cm}^{3} 1 \mathrm{M} \mathrm{C}_{2} \mathrm{H}_{7} \mathrm{NO}_{2}$ & 2 & $1: 50$ & $\begin{array}{c}\text { Shaking (to complete } \\
\text { the reaction) }\end{array}$ & 16 & Oxidizable (F3) \\
IV & $10 \mathrm{~cm}^{3}$ aqua regia & ns & $1: 10$ & Digestion $\left(130^{\circ} \mathrm{C}\right)$ & 2 & Residual (F4) \\
\hline
\end{tabular}

$R T$, room temperature; $S S R$, sample-to-solvent ratio; $n s$, not specified 


\section{Data processing}

The results from the liquid samples were processed using MS Excel 2016 software. The environmental risk indices also were obtained from calculations in MS Excel 2016. The graphs were prepared from the Excel files using Grapher 11 software.

\section{Results and discussion}

\section{Characterization of raw spent catalyst and (bio) leaching residues}

The results of phase analysis by XRD (Fig. 2a) showed that the main phase in the raw $\mathrm{SDC}$ sample was $\mathrm{SiO}_{2}$ in the form of cristobalite or tridymite, which is typically used as a porous support phase. Additional phases comprised $\mathrm{KAl}\left(\mathrm{SO}_{4}\right)_{2}$, $\mathrm{K}_{2} \mathrm{~S}_{2} \mathrm{O}_{7}, \mathrm{NH}_{4} \mathrm{VOF}\left(\mathrm{SO}_{4}\right) \cdot 3 \mathrm{H}_{2} \mathrm{O}$, and $\mathrm{V}_{2} \mathrm{O}_{5}$. The last two phases corresponded to potassium pyro-sulfo-vanadate, doped on the porous surface of the catalyst. SEM observations confirmed the existence of a porous support phase built of $\mathrm{SiO}_{2}$ and doped with V salts. Some euhedral crystals of $\mathrm{KAl}\left(\mathrm{SO}_{4}\right)_{2}$ also were embedded in the porous matrix (Fig. 2b). The composition was typical for catalysts used for oxidative desulfurization of flue gases (Mazurek 2013; Nikiforova et al. 2016). The XRD results of post-leaching residues showed that the sole remaining phases after CA and AT leaching were $\mathrm{SiO}_{2}$ polymorphs and $\mathrm{KAl}\left(\mathrm{SO}_{4}\right)_{2}$, while $\mathrm{V}$-containing phases disappeared (Fig. 2c). SEM observations of post-leaching residues showed that the remaining $\mathrm{V}$ and other elements were mixed with the support of a $\mathrm{SiO}_{2}$ phase (Fig. 2d).

The chemical composition of raw SDC material (Table 2) showed that the dominant component of the raw SDC was $\mathrm{SiO}_{2}$. The other important constituents were $\mathrm{SO}_{3}, \mathrm{~K}_{2} \mathrm{O}$, $\mathrm{V}_{2} \mathrm{O}_{5}, \mathrm{Al}_{2} \mathrm{O}_{3}, \mathrm{Na}_{2} \mathrm{O}, \mathrm{Fe}_{2} \mathrm{O}_{3}$, and $\mathrm{MgO}$. The remaining $0.4 \%$ of raw SDC consisted of elements such as $\mathrm{Ca}, \mathrm{P}, \mathrm{Ti}$, and $\mathrm{Cl}$ and other minor contaminants (data not shown). The chemical
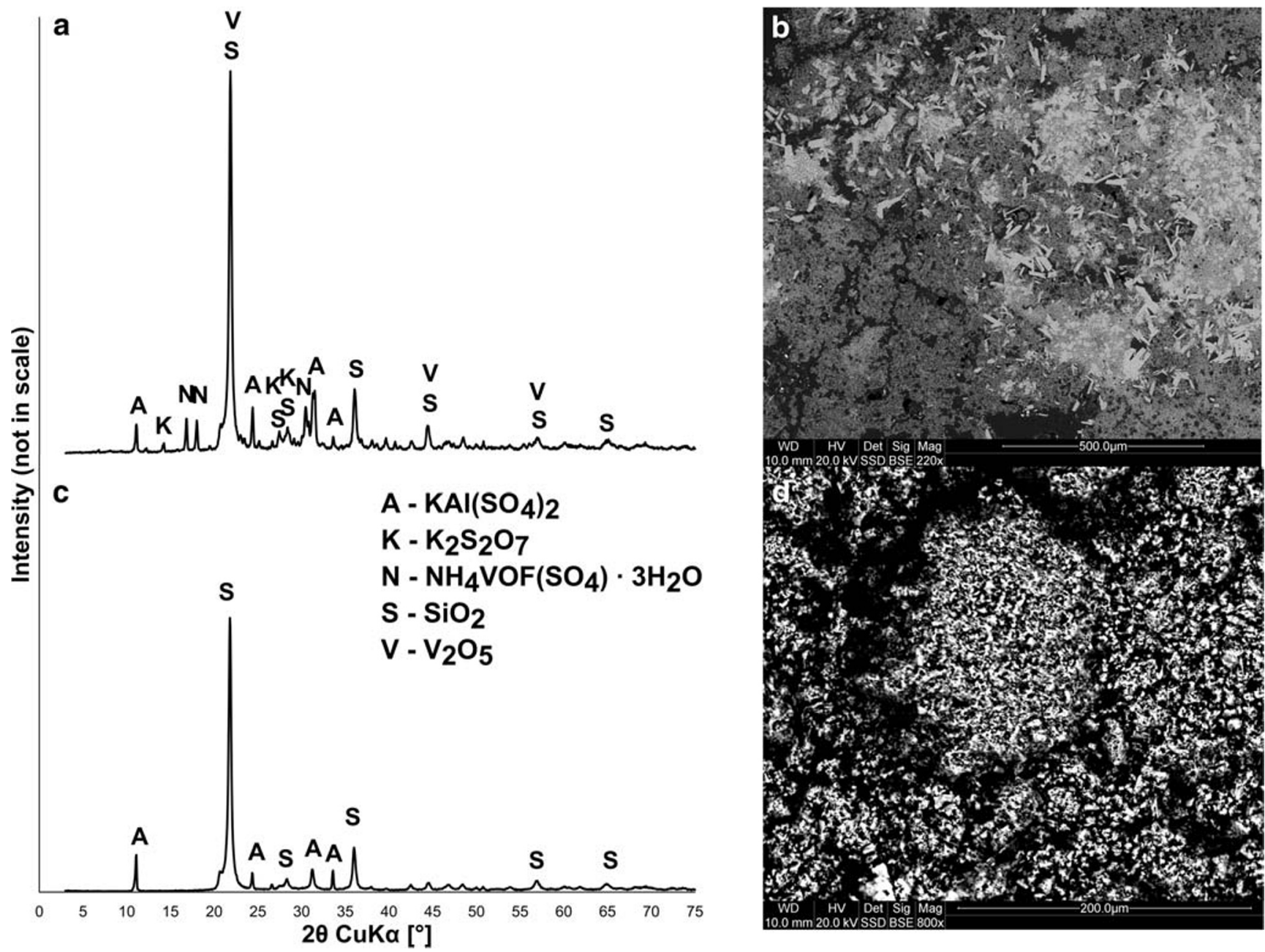

Fig. 2 a XRD pattern of raw SDC sample. b SEM photomicrograph of raw $\mathrm{SDC}$ sample, showing porous $\mathrm{SiO}_{2}$ matrix (dark gray) and $\mathrm{KAl}\left(\mathrm{SO}_{4}\right)_{2}$ euhedral crystals (light gray). c XRD pattern of leached
SDC sample. d SEM photomicrograph of leached SDC sample, showing mixed $\mathrm{SiO}_{2}$ matrix with metal remnants 
Table 2 Chemical composition (determined by WDXRF) and specific surface area (SSA; determined by BET method) of raw, acid-leached, and bioleached SDC samples

\begin{tabular}{llll}
\hline Chemical compounds (wt.\%) & Raw SDC & Acid-leached SDC & Bioleached SDC \\
\hline $\mathrm{Na}_{2} \mathrm{O}$ & 1.64 & 0.08 & 0.05 \\
$\mathrm{Al}_{2} \mathrm{O}_{3}$ & 1.67 & 1.53 & 0.51 \\
$\mathrm{SiO}_{2}$ & 65.5 & 92.0 & 96.5 \\
$\mathrm{SO}_{3}$ & 15.5 & 4.10 & 2.20 \\
$\mathrm{~K}_{2} \mathrm{O}$ & 8.77 & 1.33 & 0.35 \\
$\mathrm{~V}_{2} \mathrm{O}_{5}$ & 5.50 & 0.19 & 0.22 \\
$\mathrm{Fe}_{2} \mathrm{O}_{3} *$ & 0.73 & 0.52 & 0.13 \\
$\mathrm{MgO}$ & 0.23 & 0.06 & 0.02 \\
$\mathrm{Total}_{\mathrm{SSA}}\left[\mathrm{m}^{2} \mathrm{~g}^{-1}\right]$ & 99.6 & 99.8 & 100 \\
\hline
\end{tabular}

*Total Fe composition of CA-and AT-leached SDC samples (Table 2) revealed not only that $\mathrm{V}$ was leached to the solution but also that the concentrations of other elements were reduced compared to raw SDC. A large decrease was noted for V (ca. 96\% for both materials; Table 2). This was essential from the viewpoint of further process implementation and up-scaling. The big reduction of concentration was also noted for $\mathrm{Na}, \mathrm{Mg}, \mathrm{S}$, and $\mathrm{K}$, whereas the reduction of $\mathrm{Fe}$ and $\mathrm{Al}$ was smaller. The $\mathrm{Si}$ content increased from $65.5 \% \mathrm{SiO}_{2}$ to $92 \%$ (CA) and $96.5 \%$ (AT). The more efficient leaching of elements was noted for AT treatment, except for V (Table 2).

The BET-calculated SSA of raw and leached SDC (Table 2) showed that (bio)leaching increased the SSA of the examined residue. The SSA values were $2.34 \mathrm{~m}^{2} \mathrm{~g}^{-1}$ for raw SDC, $2.86 \mathrm{~m}^{2} \mathrm{~g}^{-1}$ for CA-leached SDC, and $3.51 \mathrm{~m}^{2} \mathrm{~g}^{-1}$ for AT-leached SDC.

\section{Metal fractionation in spent catalyst before and after (bio)leaching}

The results of the sequential extraction procedure (Fig. 3) revealed significant differentiation in metal fractionation before and after SDC treatment. For the raw SDC sample, elements such as $\mathrm{K}, \mathrm{Mg}, \mathrm{Na}$, and $\mathrm{V}$ were present mostly in exchangeable forms $(88 \%, 64 \%, 96 \%$, and $81 \%$, respectively), whereas $\mathrm{Al}$ and $\mathrm{Fe}$ were present mostly in a residual form (77\% and $66 \%$, respectively). In the CA-leached sample, much lower amounts of metals were in a mobile form $33 \%$ $\mathrm{K}, 9 \% \mathrm{Mg}, 18 \% \mathrm{Na}$, and $20 \% \mathrm{~V}$, respectively). The exceptions were $\mathrm{Al}$ and $\mathrm{Fe}$, which exhibited higher mobility (18\% $\mathrm{Al}$ vs $15 \%$ prior to leaching, $16 \% \mathrm{Fe}$ vs $9 \%$ prior to leaching). The AT treatment of SDC reduced the percentage of metals in mobile forms to an even greater extent (all elements $<10 \%$ in exchangeable fraction and $<28 \%$ in combined exchangeable/ reducible fractions). Of these, the most abundant metals in F1-F2 fractions were Fe and V (18\% and 27\%, respectively). In addition, the AT treatment of SDC transformed the examined elements into residual fractions $(93 \% \mathrm{Al}, 75 \%$ $\mathrm{Fe}, 79 \% \mathrm{~K}, 89 \% \mathrm{Mg}, 82 \% \mathrm{Na}$, and $71 \% \mathrm{~V})$. The only element present in F1-F3 fractions in raw and CA-leached samples was Na. During AT treatment, it was transferred mostly into residual fraction, which may be caused by forming clathrates and returning metals into the solid phase (Dai et al. 2018). The results showed a good agreement with earlier studies of Pathak et al. $(2014,2018)$ which showed that bioleaching spent refinery catalysts with a chemolithoautotrophic bacterium (Acidithiobacillus ferrooxidans) also could significantly reduce mobile forms of metals in this type of waste.

\section{Environmental risk assessment}

The SPLP leaching test results (Table 3) suggested that, compared to Polish wastewater regulations (RMMAIN 2019), the concentrations of the analyzed elements were exceeded, except for Na. This method evaluates the worst-case scenario for waste landfilling (Mikoda and Gruszecka-Kosowska 2018; Mikoda et al. 2019), so in this view, both raw and leached residues posed a threat to the water environment due to exceeded contents of substances particularly harmful to the aquatic environment in leachates. The load of harmful substances was much smaller in the case of CA-leached $\mathrm{SDC}$ (except for $\mathrm{Al}$ and $\mathrm{Fe}$ ). In contrast, the AT treatment significantly reduced the leachable forms of metals compared to artificial rainfall-sample contact (Table 3), leaving only $\mathrm{Al}$ and $\mathrm{V}$ in amounts that exceed regulatory values. This was another proof that bioleaching was more efficient at reducing the environmental impact of the spent catalyst.

Reduced partition indices $\left(I_{\mathrm{R}}\right.$; Table 4$)$ confirmed the decrease of risk for metals such as $\mathrm{K}$ and $\mathrm{Mg}$, expressed with higher binding strength $\left(I_{\mathrm{R}}\right.$ closer to 1$)$, when treated with CA. For $\mathrm{Na}$ and $\mathrm{V}$, the $I_{\mathrm{R}}$ values increased, but remained relatively low. The values for $\mathrm{Al}$ and $\mathrm{Fe}$ remained virtually constant, but close to 1 . This showed their high binding affinity in both 

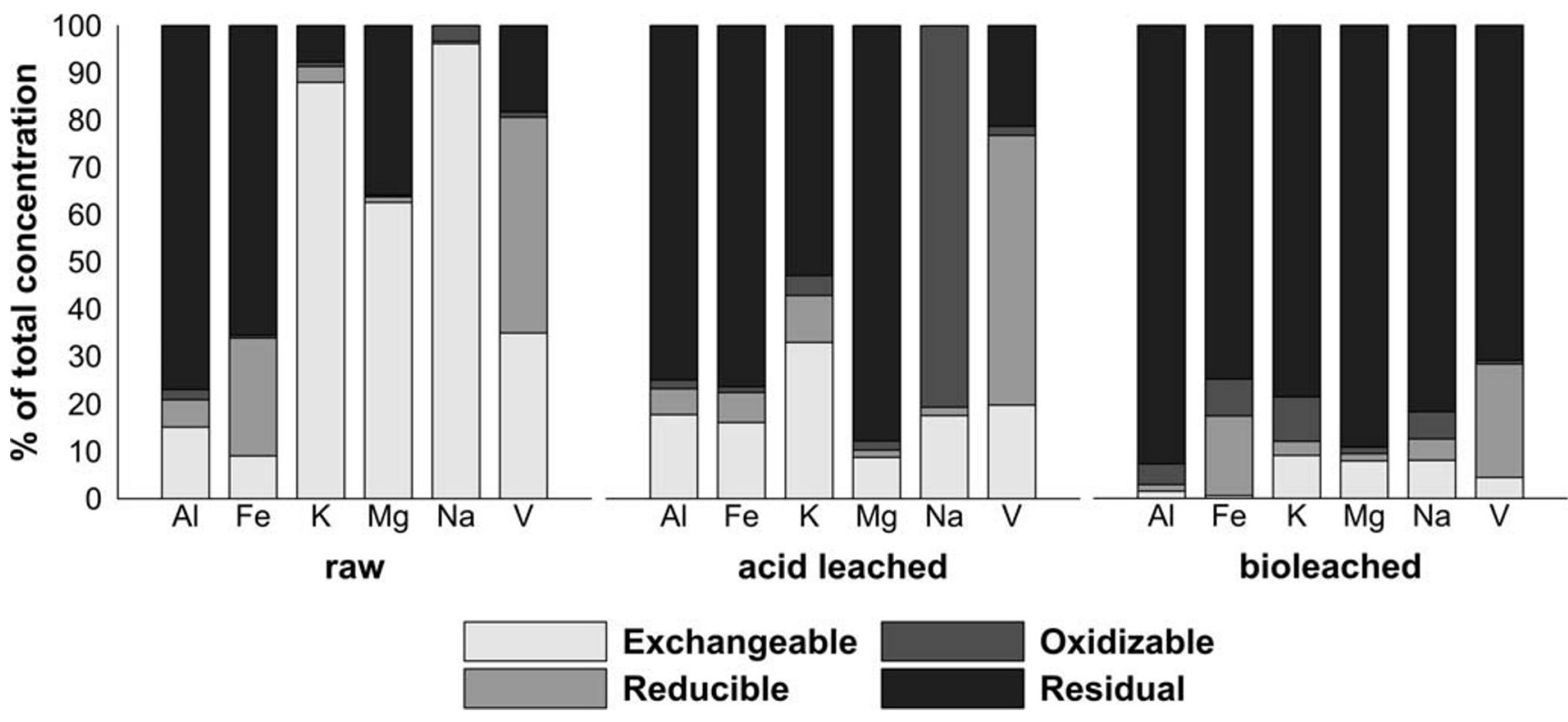

Fig. 3 Metal fractionation in raw, acid-leached, and bioleached SDC samples

materials. In the case of AT leaching, $I_{\mathrm{R}}$ values for all metals were greater than 0.77 (Table 4). This showed that their mobility was visibly decreased by bacterial leaching.

RAC values for both materials suggested that the risk was significantly lower for CA-leached SDC compared to raw SDC (Table 4). This was most visible for $\mathrm{K}$ (risk decreased from very high to high), $\mathrm{Mg}$ (risk decreased from very high to low), and $\mathrm{Na}$ (risk decreased from very high to medium). In the case of AT treatment, risk values dropped notably to low risk (for all elements) or even to the boundary of low risk/no risk for Fe (Table 4).

The present study revealed that risk indices were very good tools for expressing the environmental threat posed by waste materials and for illustrating the changes in metal fractionation profiles during treatment. The usability of risk indices in waste management and environmental science as a whole also was confirmed in other studies (Miretzky et al. 2011; Innocenzi et al. 2014; Pathak et al. 2018).

Table 3 Results of SPLP test for selected elements of raw, acidleached, and bioleached SDC samples and Polish regulatory values of these elements (RMMAIN 2019)

\begin{tabular}{lllllll}
\hline SDC sample & \multicolumn{7}{l}{ Concentration $\left[\mathrm{mg} \mathrm{dm}^{-3}\right]$} \\
\cline { 2 - 7 } & $\mathrm{Al}$ & $\mathrm{Fe}$ & $\mathrm{K}$ & $\mathrm{Na}$ & $\mathrm{S}$ & $\mathrm{V}$ \\
\hline Raw & 63 & 28 & 2941 & 589 & 4746 & 438 \\
Acid leached & 72 & 28 & 175 & 41 & 575 & 10 \\
Bioleached & 4.8 & 0.5 & 0.8 & 2.2 & 113 & 6.4 \\
Regulatory value & 3 & 10 & 80 & 800 & $200 *$ & 2 \\
\hline
\end{tabular}

*Calculated from value expressed as $\mathrm{SO}_{3}\left(500 \mathrm{mg} \mathrm{dm}{ }^{-3}\right)$

\section{Perspectives on the potential use of raw and (bio) leached catalyst}

The spent desulfurization catalyst from the copper smelting facility has the potential for further utilization, especially after bioleaching, since risk indices were low and mobile fractions of the remaining elements were scarce. The composition of all waste materials was dominated by $\mathrm{SiO}_{2}$, which suggests these materials could be used in construction engineering, e.g., as activators in cement materials (Simonsen et al. 2020). However, the amount of $\mathrm{Al}_{2} \mathrm{O}_{3}$ is too small to use these wastes as geopolymers (Trochez et al. 2015). The high amount of $\mathrm{V}$ present in the untreated material can be extracted efficiently with citric acid and Acidithiobacillus thiooxidans bacteria (up to 96\%; see Table 2). Both materials (raw and CA leached), however, pose a threat to the environment, because metals such as $\mathrm{K}, \mathrm{Mg}, \mathrm{Na}$, and $\mathrm{V}$ are easily mobilized, as demonstrated by sequential extraction, especially from raw SDC (Table 3; Table 4). On the other hand, the AT-leached residue

Table 4 Reduced partition indices $\left(I_{\mathrm{R}}\right)$ and risk assessment code (RAC) values of selected metals for raw, acid-leached, and bioleached SDC samples

\begin{tabular}{lllllllll}
\hline Indicator & SDC sample & Unit & $\mathrm{Al}$ & $\mathrm{Fe}$ & $\mathrm{K}$ & $\mathrm{Mg}$ & $\mathrm{Na}$ & $\mathrm{V}$ \\
\hline$I_{\mathrm{R}}$ & Raw & - & 0.80 & 0.73 & 0.15 & 0.40 & 0.07 & 0.33 \\
& Acid leached & & 0.78 & 0.80 & 0.60 & 0.90 & 0.33 & 0.38 \\
& Bioleached & & 0.96 & 0.83 & 0.85 & 0.91 & 0.87 & 0.78 \\
\multirow{3}{*}{$\mathrm{RAC}$} & Raw & $\%$ & 15 & 9 & 88 & 63 & 96 & 35 \\
& Acid leached & & 18 & 16 & 33 & 9 & 18 & 20 \\
& Bioleached & 2 & 1 & 9 & 8 & 8 & 4 \\
\hline
\end{tabular}


was much safer in terms of the extracted amounts of elements (Table 3; Fig. 3) and the posed risk (Table 4). In addition, the matter of using metal-free residue must be examined in the future. When comparing the specific surface area values of other spent catalysts (17-205 $\mathrm{m}^{2} \mathrm{~g}^{-1}$; Furimsky and Biagini 1996) with the ones from this study (Table 2), one can see that the SSA of raw and leached residues is very small, which is rather undesirable in the case of using the residues as a basis for new catalysts. Theoretically, high $\mathrm{SiO}_{2}$ content (> 90\%; Table 2) predestines the leached residues to be considered as sand replacement in concretes. Al-Jabri et al. (2013) showed that spent catalysts can be used as partial sand replacement in cement mortars, but those catalysts had high $\mathrm{Al}_{2} \mathrm{O}_{3}$ content, which was lacking in the SDC residues from this study. Other studies have shown that high $\mathrm{SiO}_{2}$ materials such as glass powder or waste foundry sand can be successfully used to replace sand in concrete mixtures (Islam et al. 2017; Mavroulidou and Lawrence 2019). That application, however, requires additional research on the physical parameters of the residue, such as specific gravity and moisture. Nonetheless, detailed studies of the influence of raw and leached SDC addition to concrete mixtures should be conducted to provide answers for unsolved questions about SDC utilization.

\section{Conclusions}

The present study showed that both single-step citric acid leaching and Acidithiobacillus thiooxidans bioleaching were proven efficient for metal extraction from spent desulfurization catalyst from a sulfuric acid plant. However, based on risk indices, the CA-leached catalyst might pose environmental risks, whereas the AT-leached residue created much less concern. Because biological treatment reduces metal mobility in spent catalysts, we recommend using bioleaching as an additional step in the extraction procedure or using bioleaching itself as the main method. Further utilization was hampered by low specific surface area of all examined residues, which excludes those to be used as new catalysts. However, high $\mathrm{SiO}_{2}$ content predestines the materials for further assessment, e.g., as an additive to cement mixtures.

Acknowledgments The authors would like to gratefully acknowledge Mr. Wiesław Knap for performing the ICP-MS analysis. Mr. Adam Gaweł is thanked for his help in XRD and SEM-EDS analyses. Ms. Monika Wójcik-Bania is acknowledged for performing XRF analysis. The authors also would like to express their thanks to two anonymous reviewers, whose comments helped to improve the quality and clarity of the manuscript.

Authors' contributions Conceptualization: BM; Methodology: BM, AP, AGK, EK, AT; Formal analysis and investigation: BM, AP, AT; Data curation: BM, AP, AGK; Writing — original draft: BM, AP; Writingreview and editing: BM, AP, AGK, EK, AT; Funding acquisition: BM, AP
Funding This work has been financially supported by AGH University of Science and Technology (project no. 15.11.140.003) to BM and by the National Science Centre (NCN) in Poland in the frame of the SONATA program under the grant agreement UMO-2018/31/D/ST10/00738 to AP.

Data availability Not applicable.

\section{Compliance with ethical standards}

Competing interests The authors declare that they have no competing interests.

Ethical approval Not applicable.

Consent to participate Not applicable.

Consent to publish Not applicable.

Open Access This article is licensed under a Creative Commons Attribution 4.0 International License, which permits use, sharing, adaptation, distribution and reproduction in any medium or format, as long as you give appropriate credit to the original author(s) and the source, provide a link to the Creative Commons licence, and indicate if changes were made. The images or other third party material in this article are included in the article's Creative Commons licence, unless indicated otherwise in a credit line to the material. If material is not included in the article's Creative Commons licence and your intended use is not permitted by statutory regulation or exceeds the permitted use, you will need to obtain permission directly from the copyright holder. To view a copy of this licence, visit http://creativecommons.org/licenses/by/4.0/.

\section{References}

Akcil A, Vegliò F, Ferella F, Okudan MD, Tuncuk A (2015) A review of metal recovery from spent petroleum catalysts and ash. Waste Manag 45:420-433. https://doi.org/10.1016/j.wasman.2015.07.007

Al-Jabri K, Baawain M, Taha R, Al-Kamyani ZS, Al-Shamsi K, Ishtieh A (2013) Potential use of FCC spent catalyst as partial replacement of cement or sand in cement mortars. Constr Build Mater 39:77-81. https://doi.org/10.1016/j.conbuildmat.2012.05.035

Al-Sheeha H, Marafi M, Raghavan V, Rana MS (2013) Recycling and recovery routes for spent hydroprocessing catalyst waste. Ind Eng Chem Res 52:12794-12801. https://doi.org/10.1021/ie4019148

Alvarez-Amparán MA, Cedeño-Caero L (2017) $\mathrm{MoO}_{\mathrm{x}}-\mathrm{VO}_{\mathrm{x}}$ based catalysts for the oxidative desulfurization of refractory compounds: influence of $\mathrm{MoO}_{\mathrm{x}}-\mathrm{VO}_{\mathrm{x}}$ interaction on the catalytic performance. Catal Today 282:133-139. https://doi.org/10.1016/j.cattod.2016. 07.002

Asghari I, Mousavi SM, Amiri F, Tavassoli S (2013) Bioleaching of spent refinery catalysts: a review. J Ind Eng Chem 19:1069-1081

Cecilia JA, Soriano MD, Natoli A, Rodríguez-Castellón E, López Nieto JM (2018) Selective oxidation of hydrogen sulfide to sulfur using vanadium oxide supported on porous clay heterostructures (PCHs) formed by pillars silica, silica-zirconia or silica-titania. Materials 11: 1562. https://doi.org/10.3390/ma11091562

Dai Z, Wang L, Tang H, Sun Z, Liu W, Sun Y, Su S, Hu S, Wang Y, Xu K, Liu L, Ling P, Xiang J (2018) Speciation analysis and leaching behaviors of selected trace elements in spent SCR catalyst. Chemosphere 207:440-448. https://doi.org/10.1016/j. chemosphere.2018.05.119 
Ding Y, Zhang S, Liu B, Zheng H, Chang C, Ekberg C (2019) Recovery of precious metals from electronic waste and spent catalysts: a review. Resour Conserv Recycl 141:284-298. https://doi.org/10. 1016/j.resconrec.2018.10.041

European Commission (2020) Critical raw materials resilience: charting a path towards greater security and sustainability. https://eur-lex. europa.eu/legal-content/EN/TXT/?uri=CELEX:52020DC0474 (accessed 15.10.2020)

Furimsky E, Biagini M (1996) Potential for preparation of hot gas cleanup sorbents from spent hydroprocessing catalysts. Fuel Process Technol 46:17-24. https://doi.org/10.1016/0378-3820(95)00045-3

Gusiatin ZM, Kulikowska D (2014) The usability of the $\mathrm{I}_{R}$, RAC and MRI indices of heavy metal distribution to assess the environmental quality of sewage sludge composts. Waste Manag 34:1227-1236. https://doi.org/10.1016/j.wasman.2014.04.005

Innocenzi V, Ferella F, De Michelis I, Vegliò F (2014) Treatment of fluid catalytic cracking spent catalysts to recover lanthanum and cerium: comparison between selective precipitation and solvent extraction. J Ind Eng Chem 24:92-97. https://doi.org/10.1016/j.jiec.2014.09.014

Islam GMS, Rahman MH, Kazi N (2017) Waste glass powder as partial replacement of cement for sustainable concrete practice. Int J Sustain Built Environ 6:37-44. https://doi.org/10.1016/j.ijsbe. 2016.10.005

ISO 17294-2:2016. Water quality - application of inductively coupled plasma mass spectrometry (ICP-MS) - Part 2: determination of selected elements including uranium isotopes.

Le MN, Lee MS (2020) A review on hydrometallurgical processes for the recovery of valuable metals from spent catalysts and life cycle analysis perspective. Miner Process Extr Metall Rev. https://doi.org/10. 1080/08827508.2020.1726914

Maity SK, Blanco E, Ancheyta J, Alonso F, Fukuyama H (2012) Early stage deactivation of heavy crude oil hydroprocessing catalysts. Fuel 100:17-23. https://doi.org/10.1016/j.fuel.2011.11.017

Marafi M, Stanislaus A (2008) Spent hydroprocessing catalyst management: a review: part II. Advances in metal recovery and safe disposal methods. Resour Conserv Recycl 53:1-26. https://doi.org/10.1016/ j.resconrec.2008.08.005

Marafi M, Stanislaus A, Furimsky E (2017) Handbook of spent hydroprocessing catalysts (2nd ed.). Elsevier, New York

Mavroulidou M, Lawrence D (2019) Can waste foundry sand fully replace structural concrete sand? J Mater Cycle Waste Manag 21:594-605. https://doi.org/10.1007/s10163-018-00821-1

Mazurek K (2013) Recovery of vanadium, potassium and iron from a spent vanadium catalyst by oxalic acid solution leaching, precipitation and ion exchange processes. Hydrometallurgy 134-135:26-31. https://doi.org/10.1016/j.hydromet.2013.01.011

Mikoda B, Gruszecka-Kosowska A (2018) Mineral and chemical characteristics, textural parameters, and the mobility of the selected elements of flotation waste, originating from the Polish copper-mining industry. Hum Ecol Risk Assess 24:1216-1232. https://doi.org/10. 1080/10807039.2017.1410694

Mikoda B, Gruszecka-Kosowska A, Klimek A (2017) Copper flotation waste from KGHM as potential sorbent for heavy metal removal from aqueous solutions. Hum Ecol Risk Assess 23:1610-1628. https://doi.org/10.1080/10807039.2017.1332476

Mikoda B, Kucha H, Potysz A, Kmiecik E (2019) Metallurgical slags from $\mathrm{Cu}$ production and $\mathrm{Pb}$ recovery in Poland - their environmental stability and resource potential. Appl Geochem 101:62-74. https:// doi.org/10.1016/j.apgeochem.2018.11.017

Mikoda B, Potysz A, Kucha H, Kmiecik E (2020) Vanadium removal from spent sulfuric acid plant catalyst using citric acid and Acidithiobacillus thiooxidans. Archiv Civ Mech Eng 20:132. https://doi.org/10.1007/s43452-020-00136-9

Miretzky P, Rodriguez Avendaño M, Muñoz C, Carrillo-Chavez A (2011) Use of partition and redistribution indexes for heavy metal soil distribution after contamination with a multi-element solution. $\mathrm{J}$
Soils Sediments 11:619-627. https://doi.org/10.1007/s11368-0110343-6

Muddanna MH, Baral SS (2019) A comparative study of the extraction of metals from the spent fluid catalytic cracking catalyst using chemical leaching and bioleaching by Aspergillus niger. J Environ Chem Eng 7:103335. https://doi.org/10.1016/j.jece.2019.103335

Nikiforova A, Kozhura O, Pasenko O (2016) Leaching of vanadium by sulfur dioxide from spent catalysts for sulfuric acid production. Hydrometallurgy 164:31-37. https://doi.org/10.1016/j.hydromet. 2016.05.004

Nikiforova A, Kozhura O, Pasenko O (2017) Application of lime in twostage purification of leaching solution of spent vanadium catalysts for sulfuric acid production. Hydrometallurgy 172:51-59. https:// doi.org/10.1016/j.hydromet.2017.06.020

Pathak A, Srichandan H, Kim DJ (2014) Fractionation behavior of metals (Al, Ni, V, and Mo) during bioleaching and chemical leaching of spent petroleum refinery catalyst. Water Air Soil Pollut 225:1893. https://doi.org/10.1007/s11270-014-1893-1

Pathak A, Healy MG, Morrison L (2018) Changes in the fractionation profile of $\mathrm{Al}, \mathrm{Ni}$, and Mo during bioleaching of spent hydroprocessing catalysts with Acidithiobacillus ferrooxidans. J Environ Sci Health A53:1006-1014. https://doi.org/10.1080/ 10934529.2018.1471033

Pathak A, Vinoba M, Kothari R (2020) Emerging role of organic acids in leaching of valuable metals from refinery-spent hydroprocessing catalysts, and potential techno-economic challenges: a review. Crit Rev Environ Sci Technol. https://doi.org/10.1080/10643389.2019. 1709399

Peng Z, Li Z, Lin X, Tang H, Ye L, Ma Y, Rao M, Zhang Y, Li G, Jiang T (2017) Pyrometallurgical recovery of platinum group metals from spent catalysts. JOM 69:1553-1562. https://doi.org/10.1007/ s11837-017-2450-3

Potysz A, Bartz W, Zboińska K, Schmidt F, Lenz M (2020) Deterioration of sandstones: insights from experimental weathering in acidic, neutral and biotic solutions with Acidithiobacillus thiooxidans. Constr Build Mater 246:118474. https://doi.org/10.1016/j.conbuildmat. 2020.118474

Pradhan D, Patra AK, Kim DJ, Chung HS, Lee SW (2013) A novel sequential process of bioleaching and chemical leaching for dissolving $\mathrm{Ni}, \mathrm{V}$, and Mo from spent petroleum refinery catalyst. Hydrometallurgy 131-132:114-119. https://doi.org/10.1016/j. hydromet.2012.11.004

Pradhan D, Kim DJ, Sukla LB, Pattanaik A, Lee SW (2020) Evaluation of molybdenum recovery from sulfur removed spent catalyst using leaching and solvent extraction. Sci Rep 10:1960. https://doi.org/ 10.1038/s41598-020-58972-x

Pueyo M, Mateu J, Rigol A, Vidal M, López-Sánchez JF, Rauret G (2008) Use of the modified BCR three-step sequential extraction procedure for the study of trace element dynamics in contaminated soils. Environ Pollut 152:330-341. https://doi.org/10.1016/j.envpol. 2007.06.020

RMMAIN (2019) Regulation of Ministry of Maritime Affairs and Inland Navigation on the conditions to be met as regards the release of sewage into the water or onto the land and on the substances that are particularly harmful to the aquatic environment (Off. Gazette 2019, Item 1311). http://prawo.sejm.gov.pl/isap.nsf/download.xsp/ WDU20190001311/O/D20191311.pdf (in Polish, accessed 28 Feb 2020)

Sethurajan M, Huguenot D, Jain R, Lens PNL, Horn HA, Figueiredo LHA, van Hullebusch ED (2016) Leaching and selective zinc recovery from acidic leachates of zinc metallurgical leach residues. $\mathrm{J}$ Hazard Mater 324A:71-82. https://doi.org/10.1016/j.jhazmat.2016. 01.028

Simonsen AMT, Solismaa S, Hansen HK, Jensen PE (2020) Evaluation of mine tailings' potential as supplementary cementitious materials based on chemical, mineralogical and physical characteristics. 
Waste Manag 102:710-721. https://doi.org/10.1016/j.wasman. 2019.11.037

Srichandan H, Pathak A, Singh S, Blight K, Kim DJ, Lee SW (2014) Sequential leaching of metals from spent refinery catalyst in bioleaching-bioleaching and bioleaching-chemical leaching reactor: comparative study. Hydrometallurgy 150:130-143. https://doi. org/10.1016/j.hydromet.2014.09.019

Trochez JJ, Mejía de Gutiérrez R, Rivera J, Bernal SA (2015) Synthesis of geopolymer from spent FCC: effect of $\mathrm{SiO}_{2} / \mathrm{Al}_{2} \mathrm{O}_{3}$ and $\mathrm{Na}_{2} \mathrm{O}$ / $\mathrm{SiO}_{2}$ molar ratios. Mater Constr 65:e046. https://doi.org/10.3989/ mc.2015.00814

Vogelaar BM, Eijsbouts S, Bergwerff JA, Heiszwolf JJ (2010) Hydroprocessing catalyst deactivation in commercial practice. Catal Today 154:256-263. https://doi.org/10.1016/j.cattod.2010. 03.039
Vyas S, Ting YP (2016) Sequential biological process for molybdenum extraction from hydrodesulphurization spent catalyst. Chemosphere 160:7-12. https://doi.org/10.1016/j.chemosphere.2016.06.060

Vyas S, Ting YP (2018) A review of the application of ultrasound in bioleaching and insights from sonication in (bio)chemical processes. Resources 7(1):3. https://doi.org/10.3390/resources7010003

Wiecka Z, Rzelewska-Pielut M, Cierpiszewski R, Staszak K, RegelRosocka M (2020) Hydrometallurgical recovery of cobalt(II) from spent industrial catalysts. Catalysts 10:61. https://doi.org/10.3390/ catal10010061

Publisher's note Springer Nature remains neutral with regard to jurisdictional claims in published maps and institutional affiliations. 